\title{
Dose-dependent bone-sparing effects of dietary isoflavones in the ovariectomised rat
}

\author{
Christel Picherit ${ }^{1}$, Brigitte Chanteranne ${ }^{1}$, Catherine Bennetau-Pelissero ${ }^{2}$, Marie-Jeanne Davicco ${ }^{1}$, \\ Patrice Lebecque ${ }^{1}$, Jean-Pierre Barlet ${ }^{1} *$ and Véronique Coxam ${ }^{1}$ \\ ${ }^{1}$ Groupe Ostéoporose, Laboratoire des Maladies Métaboliques et Micronutriments (U3M), I.N.R.A. Clermont-Ferrand/Theix, \\ 63122 St Genès Champanelle, France \\ ${ }^{2}$ ENITA de Bordeaux, 33175 Gradignan cedex, France
}

(Received 16 May 2000 - Revised 5 September 2000 - Accepted 22 September 2000)

\begin{abstract}
The dose-dependent bone-sparing effects of dietary isoflavones (IF) were investigated in adult (7-month-old) Wistar rats. Forty animals were ovariectomised, allocated into four groups of ten rats each, and immediately treated orally with IF at 0 (OVX), 20 (IF20), 40 (IF40) or 80 (IF80) $\mu \mathrm{g} / \mathrm{g}$ body weight per $\mathrm{d}$ for $91 \mathrm{~d}$; ten sham-operated $(\mathrm{SH})$ controls received the same diet without added IF. Animals were killed on day 91. Both femoral failure load and total femoral, diaphyseal or metaphyseal bone mineral densities (BMD) were lower in OVX animals than in SH animals. Urinary deoxypyridinoline (DPD) excretion, a marker of bone resorption, and plasma osteocalcin (OC) levels, a marker of osteoblast activity, were higher in OVX animals than in SH animals. Total femoral and diaphyseal BMD and femoral failure load were similar in IF-treated rats and SH rats. Although metaphyseal BMD in IF40 or IF80 rats was similar to that in $\mathrm{SH}$ rats, its value was lower in IF20 rats than in controls. The day 91 urinary DPD excretion in IF40 and IF80 rats, but not in IF20 rats, was similar to that in SH rats. Day 91 plasma OC concentrations in IF-treated rats were similar to day 45 values, but were decreased in OVX and SH rats. Thus, daily IF consumption prevented ovariectomy-induced bone loss, both by depressing bone resorption and stimulating osteoblast activity. Moreover, as only the highest IF level induced a weak uterotrophic activity, the optimal IF dose which preserves both cancellous and cortical bone, but exhibits no oestrogen-like effects on the uterus, was $40 \mu \mathrm{g} / \mathrm{g}$ body weight per $d$.
\end{abstract}

Dietary isoflavones: Bone: Bone protective effects

The cessation of ovarian function, and more particularly oestrogen deficiency, is the major cause of post-menopausal osteoporosis (Albright et al. 1941). Although hormonereplacement therapy (HRT) is the only consistently effective treatment to prevent post-menopausal bone loss and reduce fracture risks, it may not be prescribed to all post-menopausal women because of undesirable side effects (Taylor, 1997). Selective oestrogen receptor (OR) modulators, which bind to the OR and exhibit either oestrogenic or antioestrogenic tissue-selective properties, might be suggested as alternatives to HRT. In the same way, phyto-oestrogens, which also bind to the OR (Miksicek, 1994) with a higher binding affinity for the OR $\beta$ protein than for the OR $\alpha$ protein (Kuiper et al. 1998), may act either as antioestrogens or weak oestrogens.
Phyto-oestrogens were identified as being responsible for widespread infertility in sheep grazing on Australian pastures containing Trifolium spp. clover (Bennetts et al. 1946; Braden et al. 1967). Epidemiological studies on disease prevalence have suggested positive associations between isoflavone (IF) consumption and decreased risk of cancer, cardiovascular diseases, and even osteoporosis, given the low mortality rates for such pathologies reported in most Asian countries (Bingham et al. 1998; Anderson et al. 1999). It was recently reported that soyabean proteins containing a high concentration of IF protected postmenopausal women against spinal bone loss (Potter et al. 1998). In the ovariectomised rat classically used as animal model for post-menopausal osteoporosis (Kalu, 1991; Wronski \& Yen, 1991; Miller et al. 1995; Mosekilde,

\footnotetext{
Abbreviations: BMD, bone mineral density; DPD, deoxypyridinoline; HRT, hormone-replacement therapy; IC, initial controls; IF, isoflavones; IF20, IF40, IF80, ovariectomised rats receiving 20,40 or $80 \mu \mathrm{g}$ isoflavones/g body weight per d respectively; OC, osteocalcin; OR, oestrogen receptor; OVX, ovariectomised rats receiving no added dietary isoflavones; $\mathrm{SH}$, sham operated.

* Corresponding author: Dr Jean-Pierre Barlet, fax + 33473 624638, email picherit@clermont.inra.fr
} 
1995), bone loss is prevented by dietary soyabean proteins (Arjmandi et al. 1996) and, more particularly, their IF (Arjmandi et al. 1998), by the two main soyabean glycoside IF, genistein or daidzein (Ishida et al. 1998), and by their respective 6" 6 -o-succinylated products (Toda et al. 1999) or aglycone forms (Picherit et al. 2000). However, little is known about effective IF doses in such an animal model. The aim of the present study was therefore to investigate the dose-dependent bone-sparing effects of long-term daily IF consumption in adult ovariectomised rats.

\section{Materials and methods}

Animals and diets

The study was conducted in accordance with current legislation on animal experiments in France. Fifty-six 195d-old female Wistar rats from INRA Clermont-Ferrand/ Theix (St Genès Champanelle, France) were individually housed in a metallic cage allowing separation and collection of urine, at $21^{\circ} \mathrm{C}$, with $12 \mathrm{~h}-12 \mathrm{~h}$ light-dark cycles. Animals were fed a soyabean-protein-free powdered semi-purified diet (Table 1) from INRA Jouy en Josas (France) for $15 \mathrm{~d}$. At $210 \mathrm{~d}$ of age (body weight 310 (SE 8) g), six rats designated as initial controls (IC) were killed, and fifty other rats were intraperitoneally anaesthetised with chloral hydrate (Fluka Chemie AG, Buchs, Switzerland; $80 \mathrm{~g} / \mathrm{l}$ in saline solution $(9 \mathrm{~g} \mathrm{NaCl} / \mathrm{l}) ; 0.4 \mathrm{ml} /$ $100 \mathrm{~g}$ body weight) and either sham-operated ( $\mathrm{SH} ; n$ 10) or ovariectomised ( $n$ 40). On the first day after surgery (day 0 ), ovariectomised animals were randomly allocated to four groups of ten rats each and given IF at 0 (OVX), 20 (IF20), 40 (IF40) or 80 (IF80) $\mu \mathrm{g} / \mathrm{g}$ body weight per $\mathrm{d}$ for $91 \mathrm{~d}$. The three IF diets were prepared by mixing a powdered soyabean-IF concentrate (Novasoy ${ }^{\mathrm{TM}}$ Isoflavone compound 152-400; Archer Daniels Midland Co., Decatur, IL, USA; containing $348 \mathrm{mg}$ total IF (genistein 159, daidzein 156, glycitin 33)/g) with the semi-purified diet. SH and ovariectomised animals received the same humidified $(1 \mathrm{ml}$ water/g food) semi-purified diet without any addition. To prevent ovariectomy-induced hyperphagia,

Table 1. Composition of the soyabean-protein-free powdered semipurified diet

\begin{tabular}{lc}
\hline Ingredient $^{\star}$ & Content $(\mathrm{g} / \mathrm{kg})$ \\
\hline Casein & $180 \cdot 0$ \\
Sucrose & 210.0 \\
Maize starch & 430.0 \\
Cellulose & 100.0 \\
Peanut oil & 25.0 \\
Rapeseed oil & 25.0 \\
Vitamin mixture & 10.0 \\
Mineral mixtureł & 18.5 \\
DL-Methionine & 1.5 \\
\hline
\end{tabular}

* Sources of ingredients: casein, Union des caséinerie, Surgères, France; sucrose, Eurosucre, Paris, France; maize starch, Cerestar, Saint-Maur, France; cellulose, Durieux, Marne la Vallée, France; peanut and rapeseed oils, Bailly, Aulnay sous Bois, France; vitamin mixture, Roche, Neuilly sur Seine, France; mineral mixture, Prolabo, Fontenay sous Bois, France; DLmethionine, Jerafrance, Jeufosse, France.

$\dagger$ With cholecalciferol $32 \cdot 25 \mu \mathrm{g} / \mathrm{kg}$.

‡ With $(\mathrm{g} / \mathrm{kg})$ Ca 2.3, P 1.6, Mg $0 \cdot 42$. the daily amount of diet distributed to each rat was adjusted to the mean level consumed by SH rats on the previous day. Thus, the food intake was constant during the $91 \mathrm{~d}$ experimental period and similar in all groups. Animals had free access to water and were weighed weekly to adjust IF doses to body weight. At $48 \mathrm{~h}$ before death, the body composition was estimated by dual-energy X-ray absorptiometry (Rose et al. 1998). On day -1 for IC or day 45 and 91 for other rats, the $24 \mathrm{~h}$ urine was collected for measurement of $\mathrm{Ca}$ and deoxypyridinoline (DPD), a marker of bone resorption (Robins, 1994). Simultaneously, blood samples were harvested at 09.00 hours into ice-cooled heparinised plastic tubes containing 200 peptidase inhibitory units aprotinin (Iniprol; Choay, Paris, France)/ml blood, and centrifuged $(3500 \mathrm{~g}, 5 \mathrm{~min})$ immediately at $4^{\circ} \mathrm{C}$. Plasma was then frozen at $-20^{\circ} \mathrm{C}$ until required for measurement of phyto-oestrogens, $\mathrm{Ca}$ and osteocalcin (OC), a marker of osteoblast activity (Garnero \& Delmas, 1999). On day 91, animals were killed by cervical dislocation. Left and right femurs were cleaned from adjacent tissues and collected for mechanical testing and bone mineral density (BMD) measurement, respectively. Successes of ovariectomy and IF consumption were confirmed by uterine weight and plasma phyto-oestrogen concentration, respectively.

\section{Biochemical analysis}

Plasma phyto-oestrogen concentrations. Plasma genistein, daidzein and equol concentrations were measured by ELISA (Bennetau-Pelissero et al. 2000; Le Houérou et al. 2000). The sensitivity was 35,40 and $10 \mathrm{~nm}$ for genistein, daidzein and equol respectively. The intra- and inter-assay variations measured on ten different assays were 4.8 and $13.1 \%, 5$ and $12.8 \%$, and 5 and $13.6 \%$ for genistein, daidzein and equol respectively.

Plasma osteocalcin concentrations. Plasma OC was measured by radioimmunoassay using rat ${ }^{125}$ I-labelled OC, goat anti-rat OC antibody, and donkey anti-goat second antibody (Biochemical Technologies kit; Biochemical Technologies, Stoughton, MA, USA). The sensitivity was $0.01 \mathrm{nmol} / 1$. The intra- and inter-assay variations were 6.8 and $8.9 \%$ respectively.

Urinary deoxypyridinoline excretion. Excretion of DPD was determined by competitive radioimmunoassay, using rat monoclonal anti-DPD antibody coated to the inner surface of a polystyrene tube, and ${ }^{125}$ I-labelled DPD (Pyrilinks-D RIA kit; Metra Biosystems Inc., Mountain View, CA, USA). The sensitivity was $2 \mathrm{nmol} / \mathrm{l}$. The intraand inter-assay variations were 4 and $6 \%$ respectively. Results were expressed as nmol DPD/mmol creatinine (Robins, 1994). The urinary creatinine assay, based on a modified Jaffés's method in which picric acid forms a coloured solution in the presence of creatinine (Cook, 1975), was used to adjust DPD values for variation in urine volume.

Plasma and urinary calcium concentrations. Plasma and urinary $\mathrm{Ca}$ concentrations were assessed by atomic absorption spectrophotometry, using a Perkin Elmer 400 spectrophotometer (Perkin Elmer, Norwalk, CT, USA). Samples were previously diluted with a $\mathrm{La}_{2} \mathrm{O}_{3}$ solution 
(1 g/l; Carlo Erba Reagenti, Val de Reuil, France). The sensitivity was $2 \mu \mathrm{mol} / \mathrm{l}$ for $1 \%$ of absorption. The limit of detection was $0.025 \mu \mathrm{mol} / \mathrm{l}$.

\section{Physical analysis}

Femoral failure load. Femoral length and mean diaphyseal diameter were measured using a precision caliper (Mitutoyo, Telford, Shropshire, UK). The femoral failure load was determined using a Universal Testing Machine (Instron 4501; Instron, Canton, MA, USA), according to a threepoint bending test (Turner \& Burr, 1993). The two lower supports were separated by a $20 \mathrm{~mm}$ distance to guarantee that $85-90 \%$ of the bone flexure was due to bending. The cross-head speed was $0.5 \mathrm{~mm} / \mathrm{min}$.

Bone mineral density. BMD was assessed by dual-energy X-ray absorptiometry using a Hologic QDR-4500 A X-ray bone densitometer (Hologic, Massy, France). The total femur BMD, as well as BMD of two subregions, one corresponding to the diaphysis, which is rich in cortical bone, and the other to the distal femur metaphyseal zone, which is mainly cancellous bone, were determined (Pastoureau et al. 1995).

\section{Statistical analysis}

Results were expressed as mean with their standard errors (SE). All data were analysed using the GraphPadInStat software (Microsoft, San Diego, CA, USA). ANOVA was first performed to test for any significant differences among groups. When significant, the Student-Newman-Keuls multiple comparison test was used to determine the specific differences between means (Snedecor \& Cochran, 1967). Parametric ANOVA was performed when data were sampled from populations with equal variance. If not, non-parametric methods were selected: a Kruskall-Wallis test was first performed; if it indicated a significant difference among groups, the Mann-Whitney $U$ test was used to determine specific differences. Thus, analysis of uterine weight and plasma phyto-oestrogen concentrations was performed with non-parametric methods. The level of significance was $P<0.05$ for all statistical tests.

\section{Results}

\section{Body composition and uterine weight}

Fig. 1 shows the body weight change during the experimental period. In each group, body weight was increased between day 0 and day $91(P<0 \cdot 001)$; no significant difference was observed between groups $(P>0.05)$ on any experimental day. Fat mass (g/100 g body weight) was 23 (SE 2) in SH rats and 14 (SE 2) in IC rats $(P<0.005)$, and lean mass (g/100 g body weight) was 74 (SE 2) in SH rats and 83 (SE 2$)$ in IC rats $(P<0.005)$. The day 89 values

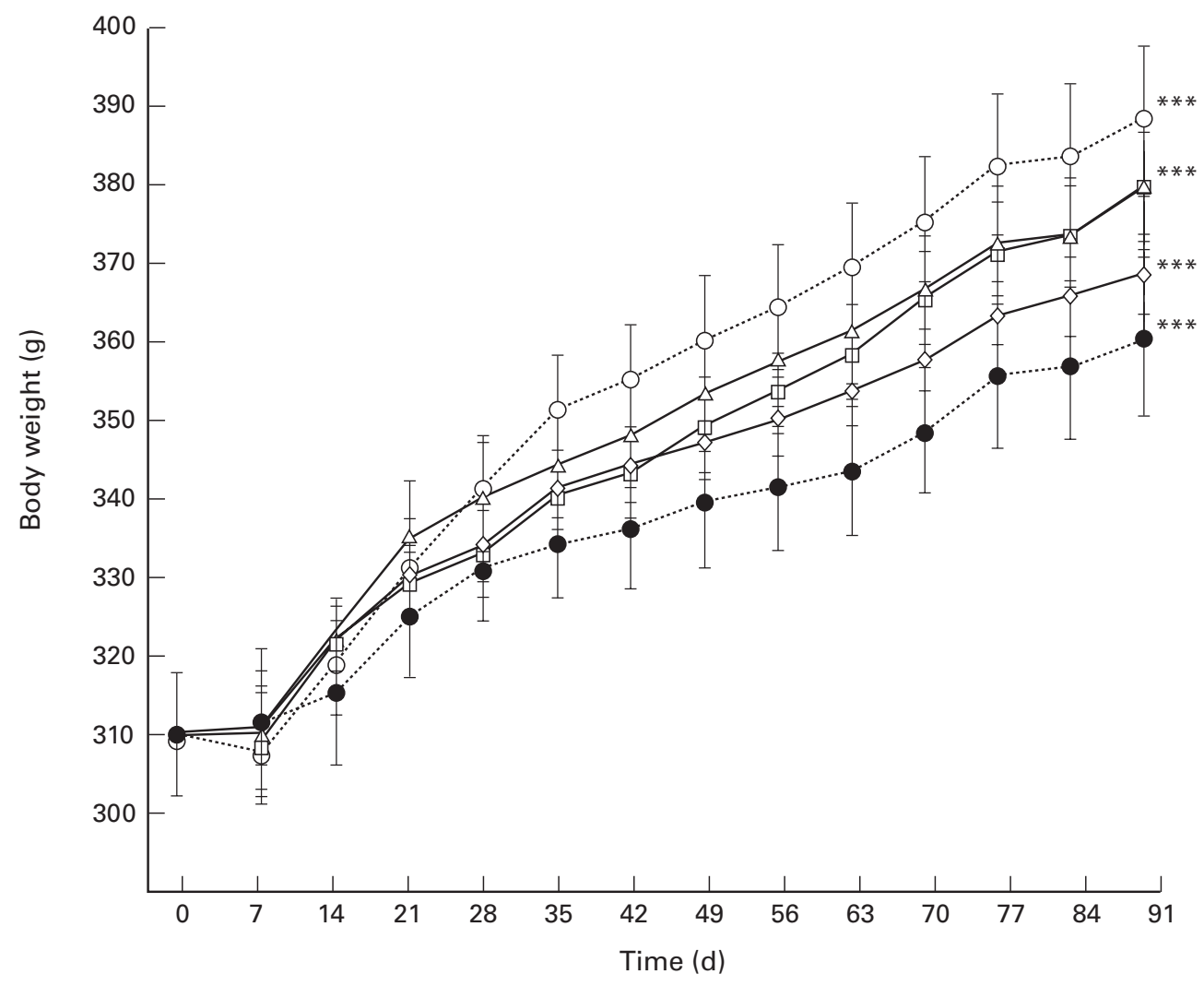

Fig. 1. Body weight changes in sham-operated $(\bullet)$ and ovariectomised rats without $(\bigcirc)$ or with isoflavones at $20(\square), 40(\triangle)$ or $80(\diamond) \mu \mathrm{g} / \mathrm{g}$ body weight per $\mathrm{d}$. Values are means with their standard errors represented by vertical bars for ten rats. Mean values were significantly different from that on day 0 : ${ }^{* \star *} P<0.001$. For details of diets and procedures, see Table 1 and p. 308. 
Table 2. Uterine weight measured in initial controls (IC), shamoperated $(\mathrm{SH})$, and ovariectomised rats without (OVX) or with isoflavones at 20 (IF20), 40 (IF40) or 80 (IF80) $\mu \mathrm{g} / \mathrm{g}$ body weight per $\mathrm{d}^{*}$

(Mean values with their standard errors)

\begin{tabular}{lclc}
\hline & & \multicolumn{2}{c}{ Uterine weight $(\mathrm{g})$} \\
\cline { 3 - 4 } Treatment group & $n$ & Mean & SE \\
\hline IC $†$ & 6 & 0.77 & 0.10 \\
SH $\ddagger$ & 10 & $0.74^{\mathrm{c}}$ & 0.07 \\
OVX $\ddagger$ & 10 & $0.18^{\mathrm{a}}$ & 0.01 \\
IF20 $\ddagger$ & 10 & $0.19^{\mathrm{a}}$ & 0.02 \\
IF40 $\ddagger$ & 10 & $0.22^{\mathrm{a}}$ & 0.03 \\
IF80 $\ddagger$ & 10 & $0.40^{\mathrm{b}}$ & 0.04 \\
\hline
\end{tabular}

a,b,c Mean values on day 91 with different superscript letters were significantly different $(P<0.005)$.

${ }^{*}$ For details of diets and procedures, see Table 1 and p. 308

$\dagger$ Values on day -1 .

$\ddagger$ Values on day 91 .

were similar between groups (fat mass 22 (SE 1), lean mass 75 (SE 1)).

As indicated in Table 2, uterine weight was not different between IC and $\mathrm{SH}$ groups $(P>0 \cdot 05)$. On day 91, uterine weight measured in OVX, IF20, IF40 and IF80 rats was lower than in $\mathrm{SH}$ rats $(P<0 \cdot 005)$. Moreover, although there was no significant change between OVX and IF20 or IF40 rats, uterine weight in IF80 rats was higher than that in OVX rats $(P<0.005)$.

\section{Biochemical analysis}

As shown in Table 3, plasma genistein, daidzein and equol concentrations on day 91 were lower in IF20 rats than in IF40 or IF80 rats $(P<0.05)$. No significant difference was observed between IF40 and IF80 rats $(P>0 \cdot 05)$. Phytooestrogen was not detected in plasma from IC, SH or OVX rats.

Fig. 2 shows plasma OC concentrations. No significant difference was observed between IC rats and the day 45 value for $\mathrm{SH}$ rats $(P>0 \cdot 05)$. However, plasma $\mathrm{OC}$ concentrations in $\mathrm{SH}$ rats decreased between days 45 and $91(P<0.05)$, inducing that the day 91 value was lower than that for IC rats $(P<0 \cdot 05)$. Similarly, plasma OC concentrations in OVX rats were lower on day 91 than on day $45(P<0 \cdot 05)$, but there was no significant difference between values on days 45 and 91 in IF20, IF40 or IF80 rats $(P>0 \cdot 05)$. Moreover, plasma OC concentrations on day 45 were significantly higher in OVX rats than in SH, IF20, IF40 or IF80 rats $(P<0 \cdot 05)$. As a result, day 91 values were reduced in $\mathrm{SH}$ rats compared with ovariectomised rats with or without IF $(P<0 \cdot 05)$.

Fig. 3 shows urinary DPD excretion. Values measured in SH rats on days 45 and 91 were similar, and not different from those in IC rats $(P>0 \cdot 05)$. Moreover, no significant change was induced between days 45 and 91 in OVX rats $(P>0.05)$, while values in IF20, IF40 or IF80 rats were lower on day 91 than on day $45(P<0 \cdot 01)$. Furthermore, urinary DPD excretion on days 45 and 91 was higher in OVX rats than in $\mathrm{SH}$ rats $(P<0.005)$, and values within $1 \mathrm{~d}$ were similar among ovariectomised rats. However, the urinary DPD excretion measured in IF40 or IF80 rats on day 91 was similar to that in $\mathrm{SH}$ rats $(P>0 \cdot 05)$.

Fig. 4 shows urinary $\mathrm{Ca}$ excretion, which was lower in IC rats than the day 45 value measured in $\mathrm{SH}$ rats $(P<$ $0 \cdot 05)$. No significant difference was observed between days 45 and 91 in SH rats $(P>0 \cdot 05)$, but the day 91 value was higher than that in IC rats $(P<0 \cdot 05)$. Urinary $\mathrm{Ca}$ excretion in OVX rats decreased between days 45 and $91(P<0.05)$, while no significant change was apparent during this period of time in IF20, IF40 or IF80 rats $(P>0.05)$. Furthermore, all groups showed the same pattern on day $45(P>0 \cdot 05)$. Thus, urinary $\mathrm{Ca}$ excretion on day 91 was lower in OVX rats than in $\mathrm{SH}$ rats $(P<0 \cdot 05)$, with those of IF20, IF40 and IF80 rats being similar to those of OVX $(P>0.05)$ and $\mathrm{SH}$ rats $(P>0.05)$. There were no significant differences in plasma $\mathrm{Ca}$ concentration between groups (2.61 (SE 0.01) $\mathrm{mmol} / \mathrm{l})$.

\section{Physical analysis}

Femoral sizes were similar in all groups (length 37.6 (SE $0 \cdot 1) \mathrm{mm}$, diameter 3.70 (SE 0.03) $\mathrm{mm}$ ). Moreover, as shown in Fig. 5, the femoral failure load was similar in IC and $\mathrm{SH}$ rats $(P>0.05)$. Day 91 values were lower in OVX rats than in $\mathrm{SH}$ rats $(P<0.05)$, while variables measured in IF20, IF40 and IF80 rats were higher than those in OVX rats and not different from those in $\mathrm{SH}$ rats.

Changes in BMD of the total femur and its diaphyseal and metaphyseal subregions are shown in Fig. 6 (A, B and $\mathrm{C}$ respectively). No significant difference was observed between IC and $\mathrm{SH}(P>0 \cdot 05)$. On day $91, \mathrm{BMD}$ was lower in OVX rats than in $\mathrm{SH}$ rats $(P<0.01)$. Total BMD in IF20, IF40 and IF80 rats was higher than that in OVX rats, and even reached the same level as that in $\mathrm{SH}$ rats. The same pattern was observed for diaphyseal BMD in IF20 and IF40 rats. Diaphyseal BMD in IF80 rats was similar to

Table 3. Plasma genistein, daidzein and equol concentrations measured in ovariectomised rats with isoflavones at 20 (IF20), 40 (IF40) or 80 (IF80) $\mu \mathrm{g} / \mathrm{g}$ body weight per $\mathrm{d} \dagger$

(Mean values with their standard errors)

\begin{tabular}{|c|c|c|c|c|c|c|c|}
\hline \multirow[b]{2}{*}{ Treatment group } & \multirow[b]{2}{*}{$n$} & \multicolumn{2}{|c|}{ Genistein $(\mu \mathrm{mol} / \mathrm{l})$} & \multicolumn{2}{|c|}{ Daidzein $(\mu \mathrm{mol} / \mathrm{l})$} & \multicolumn{2}{|c|}{ Equol $(\mu \mathrm{mol} / \mathrm{l})$} \\
\hline & & Mean & SE & Mean & SE & Mean & SE \\
\hline IF20 & 10 & 0.43 & $0 \cdot 10$ & 0.53 & $0 \cdot 18$ & 0.60 & 0.16 \\
\hline IF40 & 10 & $1.90^{*}$ & 0.42 & $2 \cdot 53^{\star \star}$ & 0.46 & $1.80^{*}$ & 0.34 \\
\hline IF80 & 10 & $4.04^{\star}$ & 1.65 & $4 \cdot 43^{\star \star}$ & 1.45 & $2 \cdot 68^{*}$ & 0.58 \\
\hline
\end{tabular}

Mean values were significantly different from those for IF20 rats: ${ }^{\star} P<0.05,{ }^{* \star} P<0.01$.

† For details of diets and procedures, see Table 1 and p. 308. 


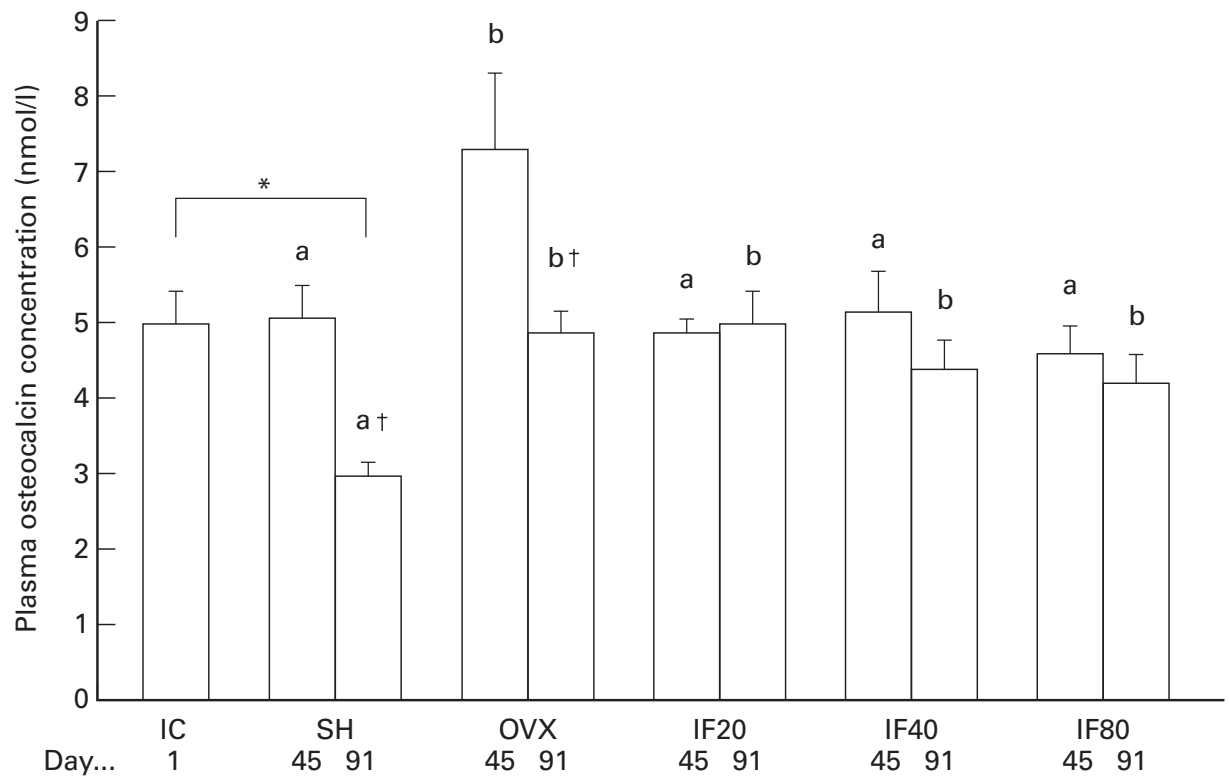

Fig. 2. Plasma osteocalcin concentrations measured in initial controls (IC), sham-operated (SH) and ovariectomised rats without (OVX) or with isoflavones at 20 (IF20), 40 (IF40) or 80 (IF80) $\mu \mathrm{g} / \mathrm{g}$ body weight per d. Values are means with their standard errors represented by vertical bars for six (IC) or ten (SH, OVX, IF20, IF40, IF80) rats. Mean value for SH rats on day 91 was significantly different from that for IC rats: ${ }^{*}<0.05$. Within a group, mean value on day 91 was significantly different from that on day $45: \dagger P<0.05$. ${ }^{\mathrm{a}, \mathrm{b}}$ For day 45 and for day 91 mean values not sharing a common letter were significantly different $(P<0.05)$. For details of diets and procedures, see Table 1 and $p .308$.

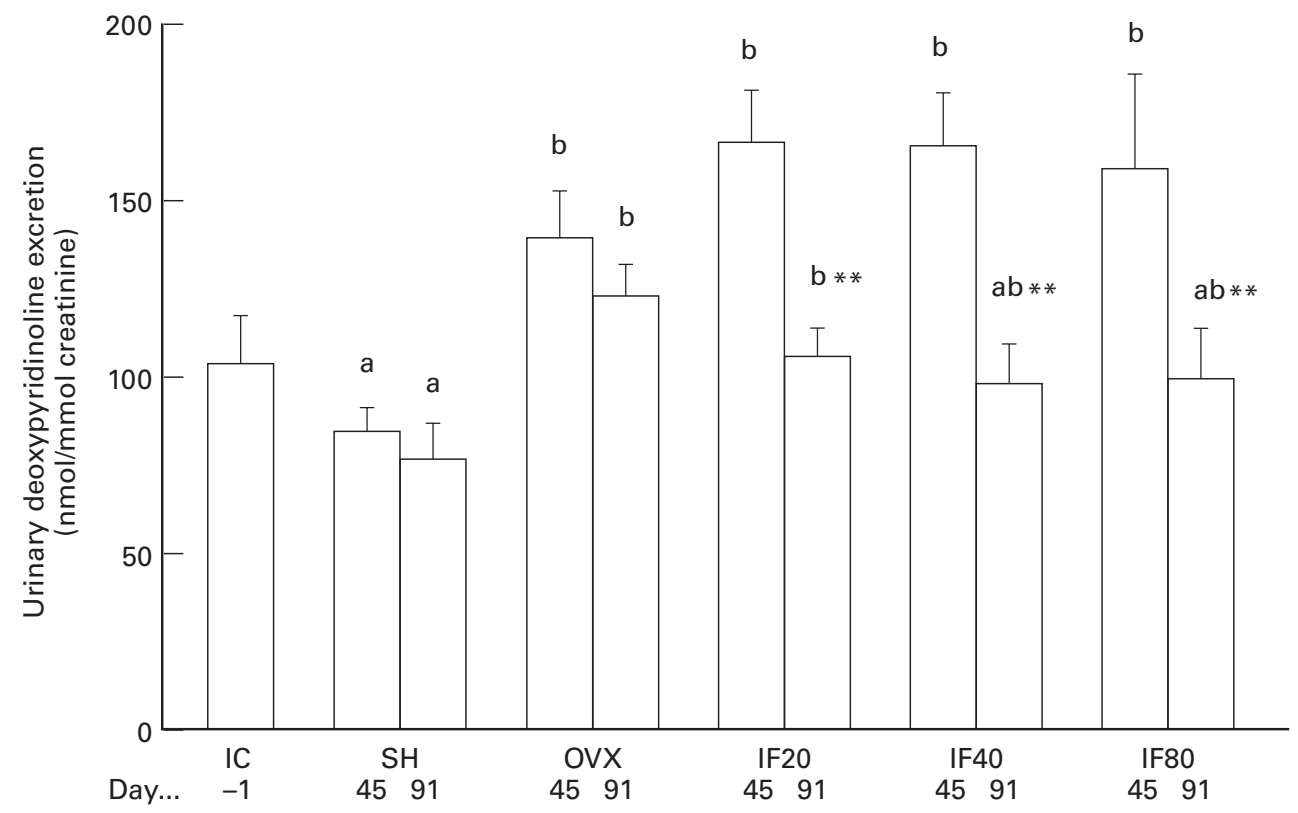

Fig. 3. Urinary deoxypyridinoline (DPD) excretion measured in initial controls (IC), sham-operated (SH) and ovariectomised rats without (OVX) or with isoflavones at 20 (IF20), 40 (IF40) or 80 (IF80) $\mu \mathrm{g} / \mathrm{g}$ body weight per $\mathrm{d}$. Values are means with their standard errors represented by vertical bars for six (IC) or ten (SH, OVX, IF20, IF40, IF80) rats. Within a group, mean value on day 91 was significantly different from that on day 45: ${ }^{* *} P<0.01$. ${ }^{a, b}$ For day 45 and for day 91 mean values not sharing a common letter were significantly different $(P<0.005)$. For details of diets and procedures, see Table 1 and p. 308. 


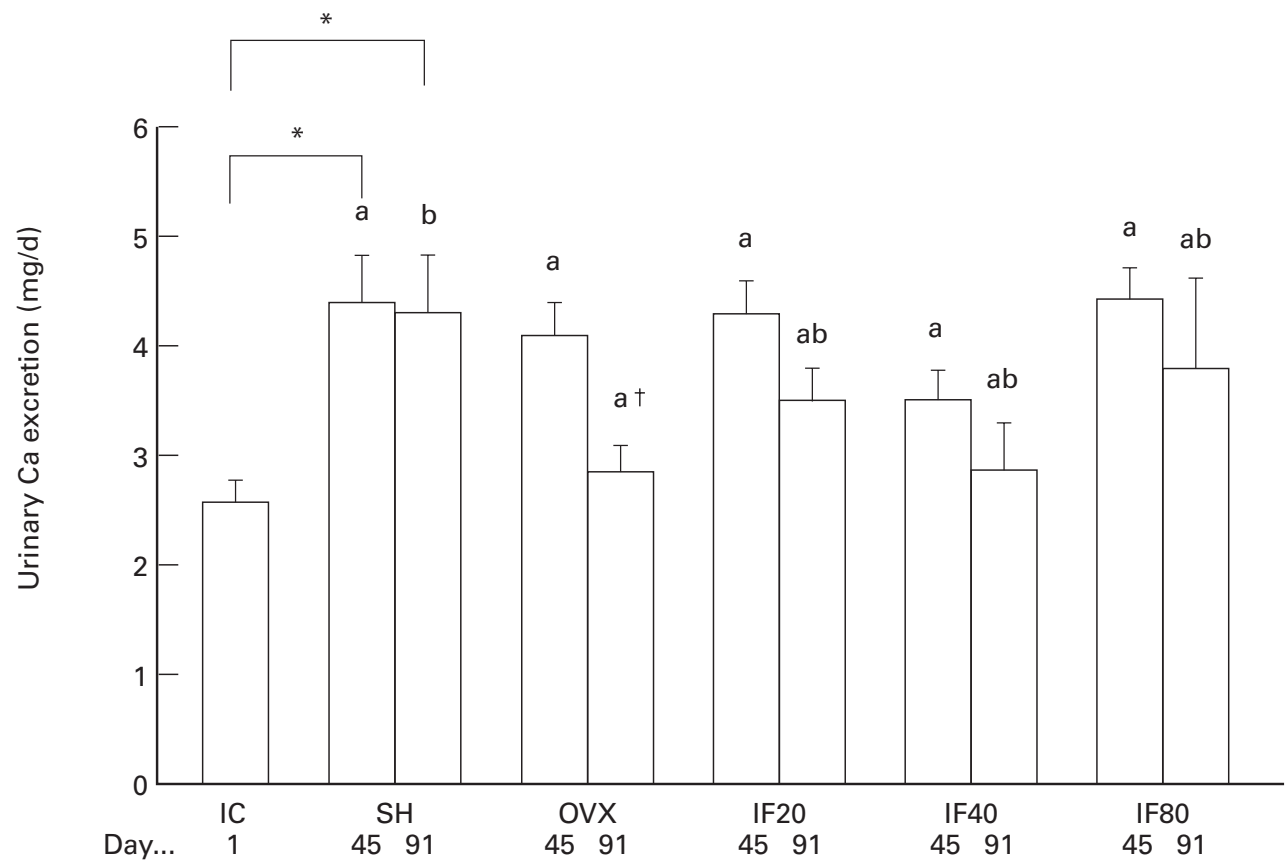

Fig. 4. Urinary calcium excretion measured in initial controls (IC), sham-operated (SH) and ovariectomised rats without (OVX) or with isoflavones at 20 (IF20), 40 (IF40) or 80 (IF80) $\mu \mathrm{g} / \mathrm{g}$ body weight per $\mathrm{d}$. Values are means with their standard errors represented by vertical bars for six (IC) or ten (SH, OVX, IF20, IF40, IF80) rats. Mean value for SH rats was significantly different from that for IC rats: ${ }^{*} P<0.05$. Within a group, mean value on day 91 was significantly different from that on day $45: \dagger P<0 \cdot 05 .{ }^{\mathrm{a}, \mathrm{b}}$ For day 45 and for day 91 mean values not sharing a common letter were significantly different $(P<0.05)$. For details of diets and procedures, see Table 1 and p. 308.

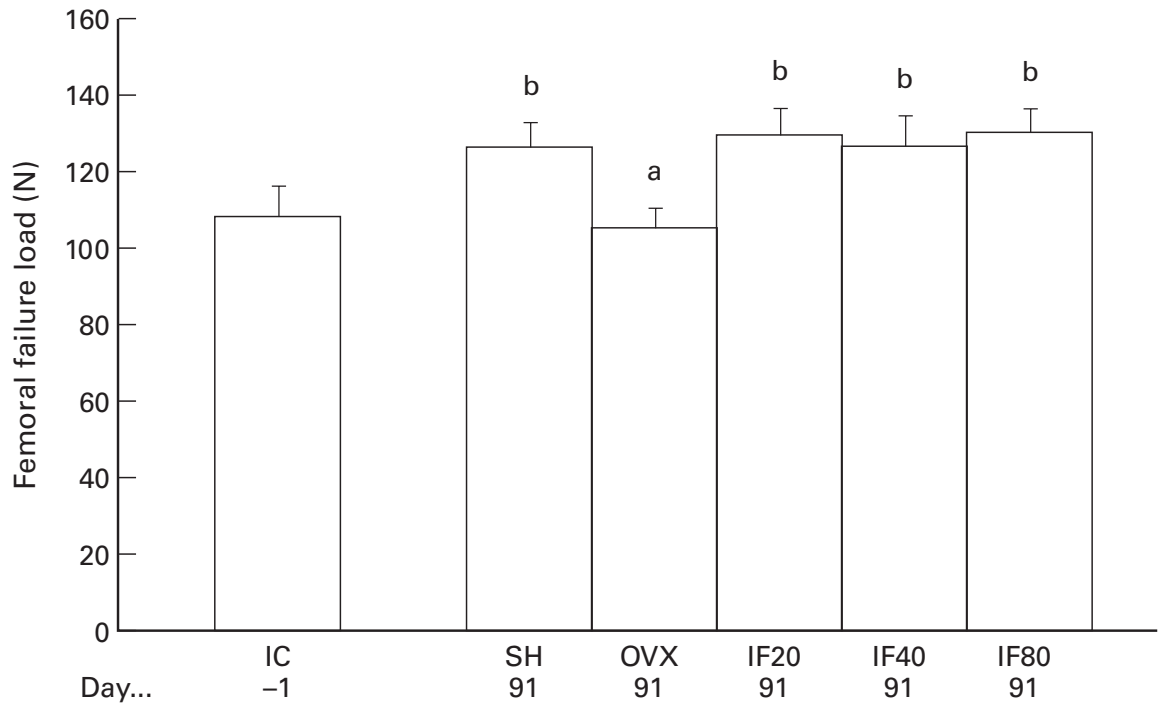

Fig. 5. Femoral failure load measured in initial controls (IC), sham-operated (SH) and ovariectomised rats without (OVX) or with isoflavones at 20 (IF20), 40 (IF40) or 80 (IF80) $\mu \mathrm{g} / \mathrm{g}$ body weight per d. Values are means with their standard errors represented by vertical bars for six (IC) or ten (SH, OVX, IF20, IF40, IF80) rats. ${ }^{a, b}$ Mean values on day 91 not sharing a common letter were significantly different $(P<0.05)$. For details of diets and procedures, see Table 1 and p. 308. 

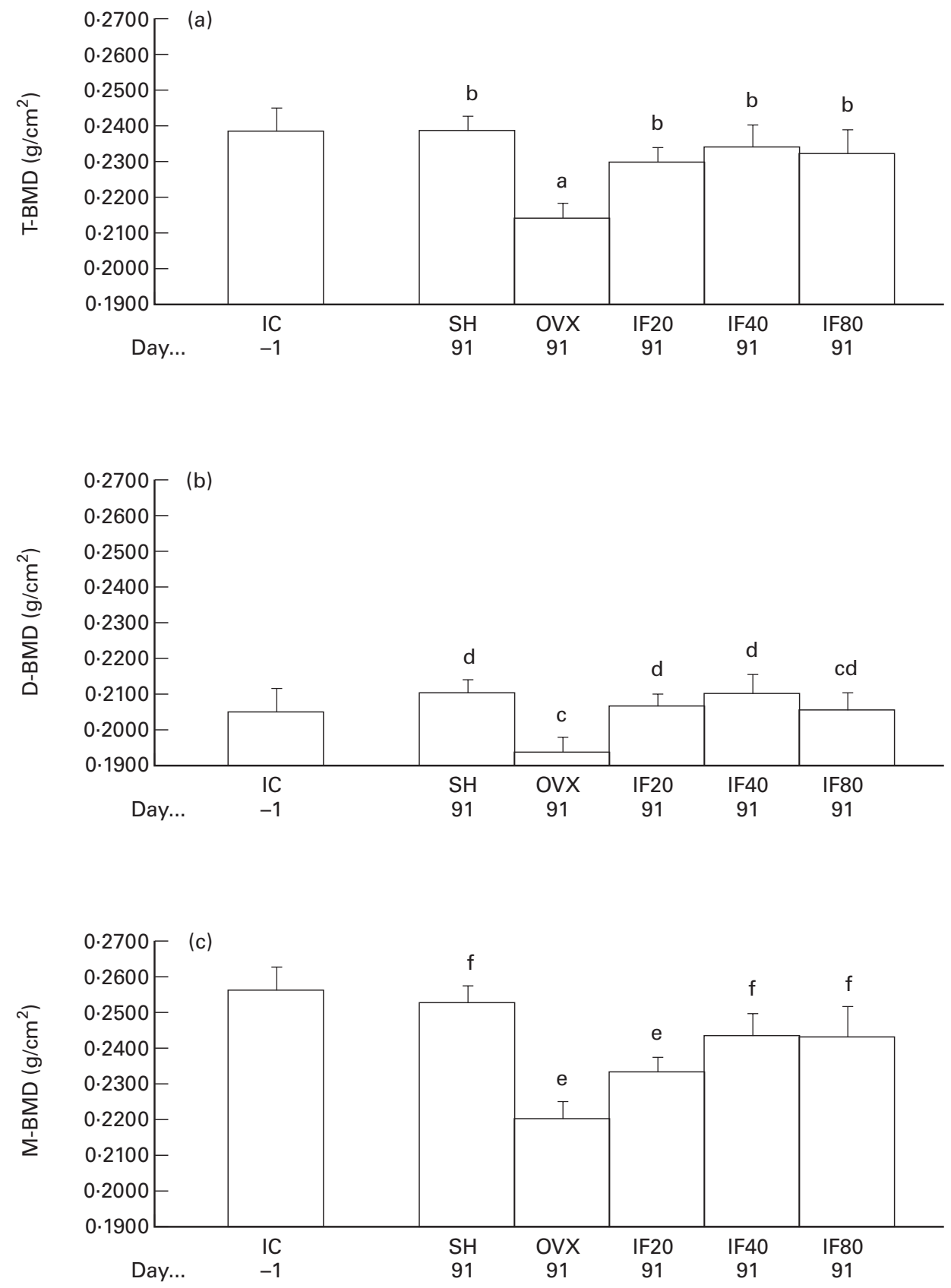

Fig. 6. (A) total femoral (T-BMD), (B) diaphyseal (D-BMD) and (C) metaphyseal (M-BMD) bone mineral densities measured in initial controls (IC), sham-operated (SH) and ovariectomised rats without (OVX) or with isoflavones at 20 (IF20), 40 (IF40) or 80 (IF80) $\mu \mathrm{g} / \mathrm{g}$ body weight per d. Values are means with their standard errors represented by vertical bars for six (IC) or ten (SH, OVX, IF20, IF40, IF80) rats. ${ }^{a, b, c, d, e, f}$ Mean values on day 91 not sharing a common letter were significantly different: ${ }^{\mathrm{a}, \mathrm{b}} P<0.005,{ }^{\mathrm{c}, \mathrm{d}} P<0.01,{ }^{\mathrm{e}, \mathrm{f}} P<0.001$. For details of diets and procedures, see Table 1 and p. 308.

that in OVX $(P>0.05)$ and SH rats $(P>0 \cdot 05)$. Finally, contrary to results obtained in IF20 rats, metaphyseal BMD in IF40 and IF80 rats was higher than that in OVX rats and similar to that in $\mathrm{SH}$ rats.

\section{Discussion}

Arjmandi et al. (1996) previously showed the bone-sparing effects of soyabean protein consumption in the young ovariectomised rat model for post-menopausal osteoporosis. Similarly, soyabean glycoside IF (Arjmandi et al. 1998), genistein or daidzein (Ishida et al. 1998), or their respective $66^{\prime \prime}-o$-succinylated products (Toda et al. 1999) were reported to protect the skeleton in the young ovariectomised rat. We recently showed that daily consumption of genistein or daidzein prevented the ovariectomy-induced osteopenia in adult rats (Picherit et al. 2000). However, the long-term dose-response effects 
of dietary soyabean IF (including both genistein and daidzein) on bone loss in adult rats have never been investigated. The present study therefore reports for the first time the dose-dependent bone-sparing effects of a soyabean IF mix given orally for $91 \mathrm{~d}$ to 7 -month-old ovariectomised rats.

Plasma phyto-oestrogen levels were increased in a dosedependent manner (Table 3), confirming the three levels of IF consumption. Such concentrations were 1000-100 000fold higher than plasma oestradiol levels, depending on the diet, the phyto-oestrogen and the physiological status of rats. Effectively, except for a rise occurring late in dioestrus with a peak at mid-pro-oestrus $(88 \mathrm{pg} / \mathrm{ml})$, the basal plasma oestradiol level throughout the $4 \mathrm{~d}$ oestrous cycle of the rat ranges from 17 to $37 \mathrm{pg} / \mathrm{ml}$ (Butcher et al. 1974). With regard to the effect of ovariectomy (confirmed by uterine atrophy 3 months later; Table 2) on bone, we observed a decrease in femoral BMD, both at cancellous and cortical sites (Fig. 6). The diaphyseal BMD reduction was also associated with an impairment of mechanical properties, as shown by the lower femoral failure load in OVX rats than in SH rats (Fig. 5). Bone loss probably resulted from an increase in bone turnover, as indicated by higher plasma OC concentration and urinary DPD excretion in OVX rats than in SH rats (Figs. 2 and 3). Pair-feeding minimised any effects of the hyperphagia and the increase in body weight that are associated with ovariectomy in rats (Kalu, 1991). As a result, fat mass was not greater in OVX rats than in SH rats. In these experimental conditions neither body weight nor body composition were influenced by daily IF consumption (Fig. 1).

As indicated in Fig. 6, IF prevented the ovariectomyinduced BMD decrease, both in the whole femur and its metaphyseal or diaphyseal subregions. Furthermore, diaphyseal BMD sparing effects were associated with a preservation of mechanical properties, as shown by the higher femoral failure load in rats receiving IF than in OVX rats (Fig. 5). These data are in accordance with previous studies, in which the oral dose of genistein and/or daidzein was about 28 (Arjmandi et al. 1998) or 50 (Ishida et al. 1998; Toda et al. 1999) $\mu \mathrm{g} / \mathrm{g}$ body weight per d. Moreover, in our experimental conditions cortical bone exhibited a greater response to IF than cancellous bone, as a diaphyseal BMD decrease was prevented by the lowest dose (IF20), while 40 or $80 \mu \mathrm{g} / \mathrm{g}$ body weight per d were needed to elicit a protective effect at the metaphyseal level (Fig. 6). Thus, in contrast to the study of Anderson et al. (1998), which used genistein, we did not observe any biphasic effect of IF on cancellous bone. This discrepancy might be explained by the fact that rats received a mix of IF, which could exhibit synergetic actions.

The cancellous bone-sparing effects of IF might result from a reduced bone resorption, as shown by the lower urinary DPD excretion on day 91 than on day 45 in ovariectomised rats receiving IF; day 91 values in IF40 or IF80 were similar to those in SH (Fig. 3). In contrast, the IF consumption at $20 \mu \mathrm{g} / \mathrm{g}$ body weight per d probably did not prevent the ovariectomy-induced bone resorption increase in the femoral metaphysis, as indicated by the day 91 urinary DPD excretion (Fig. 3). The bone-sparing effects of IF might also result from an increased osteoblast activity, as indicated by plasma OC levels which were unchanged between days 45 and 91 in ovariectomised rats receiving IF; values in OVX or SH rats were depressed during this same period of time (Fig. 2). Indeed, it was recently reported that oral administration of ipriflavone, a synthetic IF inhibiting bone resorption, could also prevent ovariectomy-induced bone loss by increasing the bone formation rate (Arjmandi et al. 2000). Moreover, as the OC content in the human femur was higher in cortical bone than in cancellous bone (Magnusson et al. 1999), the increase in plasma OC might reflect activity in the cortical bone rather than in the cancellous bone, explaining partly why cortical bone was preserved.

In contrast with bone, the uterus exhibited a lower response to IF, as only high plasma phyto-oestrogen levels (IF80) weakly increased uterine weight (Table 2). These tissue-selective IF properties resulting in bone-sparing effects associated with a non-existent or modest uterotrophic activity were frequently observed in ovariectomised rodents. Effectively, uterine weight was not increased in animals given an oral dose of genistein ranging from 1.5 to $15 \mu \mathrm{g} / \mathrm{g}$ body weight per d (Anderson et al. 1998; Picherit et al. 2000), genistein or $6^{\prime \prime}$-o-succinyl-genistein at $50 \mu \mathrm{g} / \mathrm{g}$ body weight per d (Ishida et al.1998; Toda et al. 1999), daidzein $10 \mu \mathrm{g} / \mathrm{g}$ body weight per d (Picherit et al. 2000), daidzein at 10 or $25 \mu \mathrm{g} / \mathrm{g}$ body weight per d (Ishida et al.1998), or genistein + daidzein at about $28 \mu \mathrm{g} / \mathrm{g}$ body weight per d (Arjmandi et al. 1998), whereas bone was either modestly or greatly preserved, depending on which IF was used. Only higher dietary IF doses, e.g. 40 or $80 \mu \mathrm{g}$ geinstein (Santell et al. 1997), or $50 \mu \mathrm{g}$ daidzein or $6^{\prime \prime}-o$ succinyl-daidzein/g body weight per d (Ishida et al.1998; Toda et al. 1999), weakly increased uterine weight. When given subcutaneously a genistein dose of $25 \mu \mathrm{g} / \mathrm{g}$ body weight per d (Fanti et al. 1998) was required to induce uterotrophic activity, whereas 1 or 5 (Fanti et al. 1998) or about 20 (Ishimi et al. 1999) $\mu \mathrm{g} / \mathrm{g}$ body weight per d did not increase uterine weight, while preventing bone loss. It is likely that $\mathrm{OR}$ is involved in the tissue-selective IF properties, which might depend on the predominance of one of the two OR subtypes in the target tissue. Effectively, although both $\mathrm{OR} \alpha$ and $\mathrm{OR} \beta$ proteins were detected in the rat uterus (Hiroi et al. 1999), higher expression of OR $\alpha$ mRNA than OR $\beta$ mRNA was recently reported in young intact rat uterus (Kuiper et al. 1997; Lim et al. 1999). Furthermore, both genistein and daidzein possess a greater affinity for OR $\beta$ than for OR $\alpha$ (Kuiper et al. 1997, 1998). In rat bones, although it was recently reported that expression of both OR $\alpha$ and OR $\beta$ mRNA was evident, with an OR $\beta$ mRNA predominantly expressed in osteoblasts at the metaphyseal cancellous surface (Windahl et al. 2000), and that OR $\beta$ mRNA expression was higher in cancellous bone than in cortical bone (Onoe et al. 1997), OR $\alpha: \operatorname{OR} \beta$ in cancellous or cortical bone is still unknown. Nevertheless, genistein effects might also result from various mechanisms of action, including both $\mathrm{OR}$ and non-OR-dependent pathways (Anderson et al. 1999).

In conclusion, the present study showed that daily IF consumption over a $91 \mathrm{~d}$ period in the adult ovariectomised rat model for post-menopausal osteoporosis provided bone- 
sparing effects, both by depressing bone resorption and by stimulating osteoblast activity. Moreover, the optimal IF dose which prevented both cancellous and cortical bone loss, while not exhibiting any uterotrophic activity, was $40 \mu \mathrm{g} / \mathrm{g}$ body weight per $\mathrm{d}$, including about $18 \mu \mathrm{g}$ daidzein/g body weight per $\mathrm{d}$ and $18 \mu \mathrm{g}$ genistein/g body weight per $d$. Thus, although further data are required, the bone-protective effects of IF in oestrogen-deficient animals suggest that they might be a potential nutritional alternative to HRT in human subjects.

\section{Acknowledgements}

This work was encouraged by the European Concerted Action Venus FAIR PL 4456. The authors wish to thank $\mathrm{Mr}$ J. Skrna (Archer Daniels Midland Co., Decatur, IL, USA) for generously providing the powdered soyabean IF concentrate used in this experiment.

\section{References}

Albright F, Smith PH \& Richardson A (1941) Postmenopausal osteoporosis: its clinical features. Journal of the American Medical Association 116, 2465-2474.

Anderson JJB, Ambrose WW \& Garner SC (1998) Biphasic effects of genistein on bone tissue in the ovariectomized lactating rat model. Proceedings of the Society for Experimental Biology and Medicine 217, 345-350.

Anderson JJB, Anthony M, Messina M \& Garner SC (1999) Effects of phytoestrogens on tissues. Nutrition Research Reviews 12, 75-116.

Arjmandi BH, Alekel L, Hollis BW, Amin D, StacewiezSapuntzakis M, Guo P \& Kukreja SC (1996) Dietary soybean protein prevents bone loss in an ovariectomized rat model of osteoporosis. Journal of Nutrition 126, 161-167.

Arjmandi BH, Birnbaum R, Goyal NV, Getlinger MJ, Juma S, Alekel L, Hasler CM, Drum ML, Hollis BW \& Kukreja SC (1998) Bone-sparing effect of soy protein in ovarian hormonedeficient rats is related to its isoflavone content. American Journal of Clinical Nutrition 68, S1364-S1368.

Arjmandi BH, Birnbaum RS, Juma S, Barengolts E \& Kukreja SC (2000) The synthetic phytoestrogen, ipriflavone, and estrogen prevent bone loss by different mechanisms. Calcified Tissue International 66, 61-65.

Bennetau-Pelissero C, Le Houérou C, Lamothe V, Le Menn F, Babin P \& Bennetau B (2000) Synthesis of haptens and conjugates for ELISAs of phytoestrogens. Development of the immunological tests. Journal of Agricultural and Food Chemistry 48, 305-311.

Bennetts HW, Underwood EJ \& Shier FL (1946) A specific breeding problem of sheep on subterranean clover pastures in western Australia. Australian Veterinary Journal 22, 2-12.

Bingham SA, Atkinson C, Liggins J, Bluck L \& Coward A (1998) Phyto-oestrogens: where are we now? British Journal of Nutrition 79, 393-406.

Braden AWH, Hart NK \& Lamberton JA (1967) The oestrogenic activity and metabolism of certain isoflavones in sheep. Australian Journal of Agricultural Research 18, 335-348.

Butcher RL, Collins WE \& Fugo NW (1974) Plasma concentration of LH, FSH, prolactin, progesterone and estradiol- $\beta 17$ throughout the 4-day estrous cycle of the rat. Endocrinology 94 , $1704-1708$.

Cook JGH (1975) Factors influencing the assay of creatinine. Annals of Clinical Biochemistry 12, 219-232.
Fanti P, Monier-Faugere MC, Geng Z, Schmidt J, Morris PE, Cohen D \& Malluche HH (1998) The phytoestrogen genistein reduces bone loss in short-term ovariectomized rats. Osteoporosis International 8, 274-281.

Garnero P \& Delmas PD (1999) Utilité clinique des marqueurs du remodelage osseux dans l'ostéoporose (Clinical usefulness of bone remodelling makers in osteoporosis). In Ostéoporose: progrès dans le diagnostic et la prise en charge, (Osteoporosis: Progress in Diagnosis and Management), pp. 79-101 [PJ Meunier, editor]. London: Marlin Dunitz.

Hiroi $\mathrm{H}$, Inoue S, Watanabe T, Goto W, Orimo A, Momoeda M, Tsutsumi O, Taketani Y \& Muramatsu M (1999) Differential immunolocalization of estrogen receptor $\alpha$ and $\beta$ in rat ovary and uterus. Journal of Molecular Endocrinology 22, 37-44.

Ishida H, Uesugi T, Hirai K, Toda T, Nukaya H, Yokotsuka K \& Tsuji K (1998) Preventive effects of the plant isoflavones, daidzin and genistin, on bone loss in ovariectomized rats fed a calcium-deficient diet. Biological and Pharmaceutical Bulletin 21, 62-66.

Ishimi Y, Miyaura C, Ohmura M, Onoe Y, Sato T, Uchiyama Y, Ito M, Wang X, Suda T \& Ikegama S (1999) Selective effects of genistein, a soybean isoflavone, on B-lymphopoiesis and bone loss caused by estrogen deficiency. Endocrinology 140 , 1893-1900.

Kalu DN (1991) The ovariectomized rat model of postmenopausal bone loss. Bone and Mineral 15, 175-191.

Kuiper GGJM, Carlsson B, Grandien K, Enmark E, Häggblad J, Nilsson S \& Gustafsson JA (1997) Comparison of the ligand binding specificity and transcript tissue distribution of estrogen receptors $\alpha$ and $\beta$. Endocrinology 138, 863-870.

Kuiper GGJM, Lemmen JG, Carlsson B, Corton JC, Safe SH, Van Der Saag PT, Van Der Burg B \& Gustafsson JA (1998) Interaction of estrogenic chemicals and phytoestrogens with estrogen receptor $\beta$. Endocrinology 139, 4252-4263.

Le Houérou C, Bennetau-Pelissero C, Lamothe V, Le Menn F, Babin P \& Bennetau B (2000) Syntheses of novel haptenprotein conjugates for production of highly specific antibodies to formononetin, daidzein and genistein. Tetrahedron 56, 295301.

Lim SK, Won YJ, Lee HC, Huh KB \& Park YS (1999) A PCR analysis of $\mathrm{ER} \alpha$ and $\mathrm{ER} \beta$ mRNA abundance in rats and the effect of ovariectomy. Journal of Bone and Mineral Research 14, 1189-1196.

Magnusson P, Larsson L, Magnusson M, Davie MWJ \& Sharp CA (1999) Isoforms of bone alkaline phosphatase: characterization and origin in human trabecular and cortical bone. Journal of Bone and Mineral Research 14, 1926-1933.

Miksicek RJ (1994) Interaction of naturally occurring nonsteroidal estrogens with expressed recombinant human estrogen receptor. Journal of Steroid Biochemistry and Molecular Biology 49, $153-160$.

Miller SC, Bowman BM \& Jee WSS (1995) Available animal models of osteopenia - small and large. Bone 17, S117-S123.

Mosekilde L (1995) Assessing bone quality-animal models in preclinical osteoporosis research. Bone 17, S343-S352.

Onoe Y, Miyaura C, Ohta H, Nozawa S \& Suda T (1997) Expression of estrogen receptor $\beta$ in rat bone. Endocrinology 138, 4509-4512.

Pastoureau P, Chomel A \& Bonnet J (1995) Specific evaluation of localized bone mass and bone loss in the rat using dual energy $\mathrm{X}$-ray absorptiometry subregional analysis. Osteoporosis International 5, 143-149.

Picherit C, Coxam V, Bennetau-Pelissero C, Kati-Coulibaly S, Davicco MJ, Lebecque P \& Barlet JP (2000) Daidzein is more efficient than genistein in preventing ovariectomy-induced bone loss in rats. Journal of Nutrition 130, 1675-1681.

Potter SM, Baum JO, Teng H, Stillman RJ, Shay NF \& 
Erdman JW Jr (1998) Soy protein and isoflavones: their effects on blood lipids and bone density in postmenopausal women. American Journal of Clinical Nutrition 68, 1375S-1379S.

Robins SP (1994) Biochemical markers for assessing skeletal growth. European Journal of Clinical Nutrition 48, S199S209.

Rose BS, Flatt WP, Martin RJ \& Lewis RD (1998) Whole body composition of rats determined by dual energy X-ray absorptiometry is correlated with chemical analysis. Journal of Nutrition 128, 246-250.

Santell RC, Chen Chang Y, Nair MG \& Helferich WG (1997) Dietary genistein exerts estrogenic effects upon the uterus, mammary gland and the hypothalamic/pituitary axis in rats. Journal of Nutrition 127, 263-269.

Snedecor GW \& Cochran WG (1967) Statistical Methods, 6th ed. Ames, IA: Iowa State University Press.
Taylor M (1997) Alternatives to conventional hormone replacement therapy. Comparative Therapies 23, 514-532.

Toda T, Uesugi T, Hirai K, Nukaya H, Tsuji K \& Ishida H (1999) New 6-o-acyl isoflavone glycosides from soybeans fermented with Bacillus subtilis (natto). I. 6-o-succinylated isoflavone glycosides and their preventive effects on bone loss in ovariectomized rats fed a calcium-deficient diet. Biological and Pharmaceutical Bulletin 22, 1193-1201.

Turner CH \& Burr CB (1993) Basic mechanical measurements of bone: a tutorial. Bone 14, 595-608.

Windahl SH, Norgard M, Kuiper GGJM, Gustafsson JA \& Andersson G (2000) Cellular distribution of estrogen receptor $\beta$ in neonatal rat bone. Bone 26, 117-121.

Wronski TJ \& Yen CF (1991) The ovariectomized rat as an animal model for postmenopausal bone loss. Cells and Materials Suppl. 1, S69-S74. 